\title{
The big five personality traits influencing habitual Facebook usage, life satisfaction and psychological well-being of Generation Y students
}

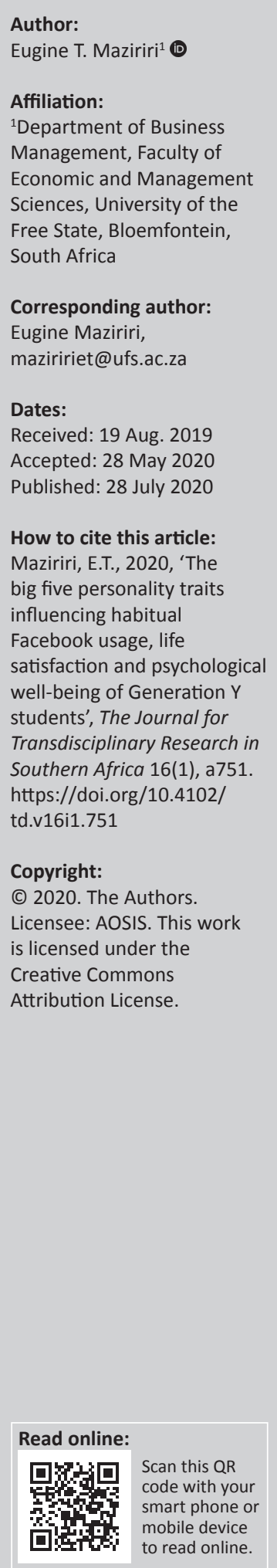

Affiliation

${ }^{1}$ Department of Business

Management, Faculty of Economic and Management Sciences, University of the Free State, Bloemfontein, South Africa

Corresponding author: Eugine Maziriri, maziririet@ufs.ac.za

Dates: Published: 28 July 2020

How to cite this article: Maziriri, E.T., 2020, 'The influencing habitual Facebook usage, life well-being of Generation $Y$ students', The Journal for Transdisciplinary Research in https://doi.org/10.4102/ td.v16i1.751

Copyright: Licensee: AOSIS. This work is licensed under the Creative Commons Attribution License.

\begin{abstract}
This research determined five big personality traits that influenced South African Generation Y students' habitual use of Facebook, life satisfaction and psychological well-being. The research embraced a quantitative approach, and a structured questionnaire was used to obtain information from Generation Y students. The data were analysed using Smart PLS software version 3.2.7 for partial least square structural equation modelling (PLS-SEM). Neuroticism, extraversion, openness and agreeableness had positive and significant influences on habitual Facebook usage (HFU). However, conscientiousness seemed to have a positive yet insignificant relationship with HFU. Habitual use of Facebook has been found to have a positive and significant impact on life satisfaction and psychological well-being. It was also determined that life satisfaction positively and significantly influences psychological well-being. The exogenous-to-endogenous outcomes from the structural model coincided with most of prior study's findings. Therefore, in the light of the associated literature, the findings were discussed. This study is intended to add a fresh understanding to the current body of Africa's personality, psychology and social media literature - a context that has received little research attention in developing nations.
\end{abstract}

Keywords: neuroticism; extraversion; openness; agreeableness; conscientiousness; habitual Facebook usage; life satisfaction; psychological well-being.

\section{Introduction}

Individuals can be categorised based on various parameters, such as their height, weight, gender, age, generation and level of education, as well as their character (Naude et al. 2016). Furthermore, Bergh (2009) confirmed that personality is probably one of the most significant fields to be regarded in the research on human nature and differences, as well as similarities between individuals. The best personality domain can be best defined by the Five Factor Model (FFM) using the Big Five Personality Dimensions (Acopio \& Bance 2016). This model conceptualises the hierarchy of personality traits in a series of five simple dimensions, namely, neuroticism, extraversion, openness to experience, agreeableness and conscientiousness (Ali 2019; Mhlanga 2019; Szcześniak, Sopińska \& Kroplewski 2019). As this model has identified its utility for both clinical methods and empirical research projects (Costa \& McCrae 1992), this study aims to use it as a theoretical basis for generating projections among the above-mentioned variables. Precisely, this research explains how the ownership of certain personality traits by Generation Y Facebook users will affect their usual use of Facebook as well as the extent to which its use affects the fulfilment of their lives and their psychological well-being as students. Johnson (2015) argued that it is worth exploring how the characteristics of an individual can contribute to Facebook habits because of the interactivity available in today's media.

In spite of the ability to provide important insights into personality traits, it is essential to note that there is still a shortage of empirical evidence of relationships between neuroticism, extraversion, openness, agreeableness, conscientiousness, habitual Facebook usage (HFU), life satisfaction and psychological well-being. Consequently, further scholarly introspections are considered necessary. Much of what is written on the subject is based on samples from developed countries such as India, Malaysia, Turkey, Norway, Finland and Canada, among others. For example, among students enrolled for the Bachelor of Technology (B.Tech) degree in India, Murugesan and Jayavelu (2017) examined the influence of big five personality traits and self-efficacy on entrepreneurial intention (Murugesan \& Jayavelu 2017). Furthermore, Lotfi et al. (2016) explored the impact of personality traits (extraversion, openness, awareness, agreeability and 
neuroticism) on knowledge-sharing conduct among students at a Malaysian public university. Furthermore, in 10 small- and medium-sized hotels located in Turkey, Yesil and Sozbilir (2013) determined the impact of personality features on the individual innovation conduct of 215 staff. In addition, Vaag, Sund and Bjerkeset (2018) determined five-factor personality profiles among Norwegian musicians, compared with the general workforce. Furthermore, Heinström (2003) also performed a survey focussed on the connection between five dimensions of personality and their impact on Finnish students' data behaviour. In addition, Oyibo, Orji and Vassileva (2017) examined the impact of personality traits among a sample of 216 Canadians on Cialdini's persuasive approaches.

In spite of the increasing body of personality trait research, there is still a lack of comprehension of the effect of neuroticism, extraversion, openness, agreeableness and conscientiousness on HFU, life satisfaction, as well as psychological well-being of South African Generation Y Students. Previous academics have performed their research in different environments within the South African context, by concentrating on the role of the five major variables in predicting job creation propensities among administrative staff in a South African tertiary institution (Bell \& Njoli 2016); the connection between personality dimensions and work performance of staff of a corporate pharmacy group in the North West Province, the Free State, Mpumalanga and Gauteng (Rothmann \& Coetzer 2003); the connection between the five major personality characteristics and burnout in South African college learners (Morgan \& De Bruin 2010); assessment of personality characteristics connected with work satisfaction among South African anaesthetists using the Big Five Inventory (Kisten \& Kluyts 2018); exploration of personality characteristics, carefulness and feeling of consistency among females in Greater Schooling South Africa (Mayer, Surtee \& Visser 2016); and personality characteristics and resilience as predictors of work pressure and burnout among call centre workers (Lamb 2009).

While these studies are informative, they did not examine how neuroticism, extraversion, openness, agreeableness and conscientiousness influence HFU, life satisfaction and psychological well-being of Generation $Y$ Students in South Africa. This article therefore helps to tackle the gap by using a sample of Generation Y students from a context in a developing country. Very few (if any) researchers have used structural equation modelling (SEM) to test the relationships of neuroticism, extraversion, openness, agreeableness, conscientiousness, HFU, life satisfaction and psychological well-being of South African Generation Y students. With regard to the conceptual model proposed in this study, it can be noted that it is one of a kind, as no previous study has tested the variables in the proposed model in relation to the South African context to the best knowledge of the researcher.

This article is organised as follows: firstly, a study context is given, followed by a theoretical model and a creation of the hypothesis. The research design and methodology are then presented, followed by a presentation of the results and the discussion. The final sections of the article discuss the implications, limitations and future research directions.

\section{Contextualisation of the study} Facebook

Facebook exists as a virtual community that enables users to belong to different communities created on the network to enable social requirements to be met (Viljoen, Dube \& Murisi 2016). According to Bevan-Dye and Akpojivi (2016), Facebook has experienced phenomenal development, and in South Africa, the site is particularly popular among young people between the ages of 18 and 24 who are part of the Generation Y cohort (persons born between 1986 and 2005). In 2019, Facebook reported almost 1.58 billion daily active users, and there were more than 2 billion monthly active users in July 2019 (Statista 2019). Hence, there has been a rapid expansion in the use of Facebook, and it has become an international phenomenon (Foroughi et al. 2019). Facebook is of great importance in young consumers' decision-making (Chininga et al. 2019). In addition, Chakraborty (2016) confirmed the positive influences of using Facebook on individuals' social lives, such as forming new relationships, bonding, social capital, and improving and maintaining real friendship networks. Moreover, Houghton, Pressey and Istanbulluoglu (2019) found Facebook use drives satisfaction with life based on connections with other users - akin to the need of belonging - again suggesting that satisfaction is achieved on the fulfilment of needs.

\section{The motivation and significance of choosing generation $\mathrm{Y}$ students}

Jariangprasert et al. (2019) stated that Generation Y is technology savvy and a visually advanced generation, making it easy for them to adapt to the advent of new technology and use it from a very young age. As this generation grew up in the digital era, technology has always played a key role in their lives (Van Deventer \& Lues 2019). Therefore, it is not surprising that Generation $Y$ spends a significant amount of time shopping on the Internet, interacting with social networking sites (SNSs), staying up to date on the latest news and trends, and having fun (Van Deventer \& Lues 2019). In addition, participation of Generation Y students is essential for social networking studies, given that $\mathrm{Chu}$ and Kim (2011:58) claimed that students constitute the majority of users of SNSs, with Facebook being reported as the most common online SNSs among higher education institution (HEI) students (Cheung, Chiu \& Lee 2011). Moreover, Bevan-Dye and Akpojivi (2015) asserted that the Generation $Y$ cohort uses Facebook as a platform to interact with friends and family, to discover and connect with colleagues and to express their views and opinions. The abovementioned contention offers evidence that it is essential to examine the Generation Y cohort. 


\section{Theoretical model and hypotheses formulation}

Drawing on the above, the study's research model was developed (Figure 1). The theoretical model illustrates the suggested interconnection of eight constructs, namely, neuroticism, extraversion, openness, agreeableness, conscientiousness, habitual Facebook use, life satisfaction and psychological well-being. The relationships between the proposed constructs in the theoretical model are as follows: neuroticism, extraversion, openness, agreeableness and conscientiousness provide the starting point of the model and directly affect habitual Facebook use which, in turn, induces life satisfaction and psychological well-being. Finally, the theoretical model proposes that life satisfaction will lead to psychological well-being. The following sections will review the literature on the study's main variables. Moreover, the hypothesised connections between the study variables are discussed in the subsequent sections based on past studies and logically deriving from prior results.

\section{Neuroticism and habitual Facebook usage}

Neuroticism, or low emotional stability, refers to the tendency to experience negative emotions and the behaviours that accompany them (Peral \& Geldenhuys 2020). Neurotic people have an anxious general predisposition and a tendency to worry (Mehroof \& Griffiths 2010). Previous empirical studies have shown substantial evidence of the positive relationship between neuroticism and electronic word-of-mouth of social media advertisements (Dodoo \& Padovano 2020), welfare state attitudes (Tepe \& Vanhuysse 2020) and online video ads sharing intention (Choi 2020). However, within the context of this study, it is important to understand how neuroticism influences HFU among Generation Y students. Hence, this study will close this gap by empirically testing the relationship of these two variables. Neuroticism is central to and a predictor of SNSs' use and engagement (Blackwell et al. 2017; Ul Islam et al. 2017). Facebook users with a high level of neuroticism regularly use the site, typically revisiting it frequently, but staying linked for a short time (Correa et al. 2013). This behavioural pattern may lead from elevated rates of anxiety in people with greater neuroticism characteristics, which may be explained by an enhanced need for social support (Ross et al. 2009).

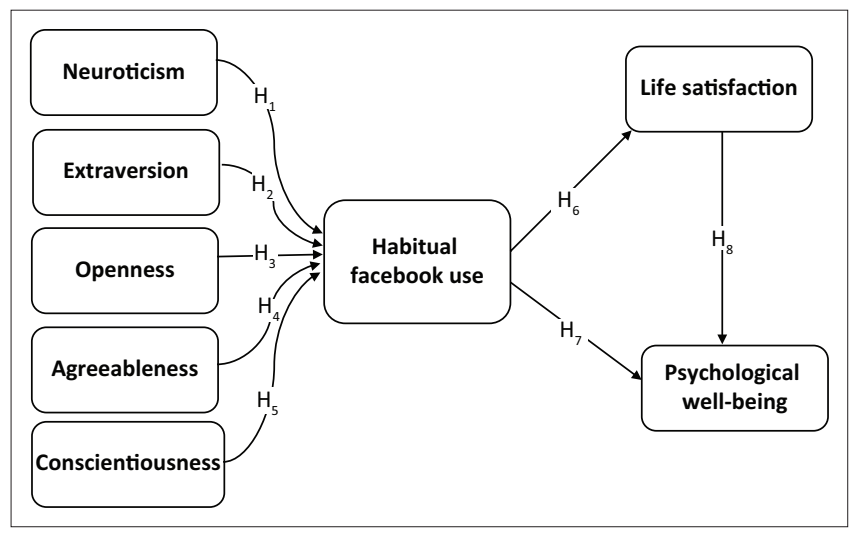

FIGURE 1: Theoretical model.
Indeed, highly neurotic people are more likely to use the web to decrease solitude (Butt \& Phillips 2008). Drawing from the preceding theoretical discussion and also in line with the empirical evidence on neuroticism and HFU, this study hypothesises that:

H1: Neuroticism positively and significantly impacts habitual Facebook usage among Generation Y students.

\section{Extraversion and habitual Facebook usage}

Extraversion is described as a person's propensity to seek stimulation and enjoy other people's connection (Ruzungunde \& Mjoli 2020). Extraverts are energised by social interactions and are seen as outgoing, sociable and friendly people (Peral \& Geldenhuys 2020). Previous scholars have discovered extraversion as an antecedent or predictor of mutual investment decision (Bindu 2020), self-reported competitiveness (Fong, Zhao \& Smillie 2020), customer engagement and relationship duration (Itani, El Haddad \& Kalra 2020). Deducing from the aforementioned research studies, it can be noted that there is scant evidence in studies that have examined how extraversion would influence HFU. Hence, this study will close this lacuna by empirically testing the nexus between extraversion and HFU. Extraverts are also discovered using Facebook to interact with friends and contacts as a means of social expansion (Ryan \& Xenos 2011). Extraverts are more likely to be frequent users of social media and display higher engagement with Facebook (Dodoo \& Padovano 2020). Furthermore, Moore and McElroy (2012) also discovered a favourable connection in their research between the use of one's Facebook and the extraversion trait. Extraverts are more likely to reach out and communicate on Facebook with individuals; they are more involved in sharing their whereabouts, their emotions with others and letting others react to them (Sharma \& Jaswal 2015). Extraverts are more involved in political problems by exchanging pictures with others via Facebook (Quintelier \& Theocharis 2013). Consequently, drawing from the above discussion and past empirical evidence, the current study hypothesises that:

H2: Extraversion positively and significantly impacts habitual Facebook usage among Generation Y students.

\section{Openness and habitual Facebook usage}

Openness is a trait that describes outgoing, excited and daring individuals who love challenges (Jeronimus et al. 2014). It defines people who are open to changing their own outlook and what they want from others (Mondak 2010). Previous empirical studies of different contexts have shown a positive association between openness and individuals' willingness to pay for organic food (Gustavsen \& Hegnes 2020), visitor's experience, emotional stimulation and behaviour (Leri \& Theodoridis 2020), and attitudes towards homosexuality (Metin-Orta \& Metin-Camgöz 2020). Against the aforementioned background, within the context of this study, it is important to understand how openness would influence HFU among Generation Y students. Hence, there is a need to close this gap by assessing the association 
between openness and HFU. Openness to experience has been found to be associated with SNS use (Muscanell \& Guadagno 2012), as it entices people who are open to experiences (Correa, Hinsley \& Zúñiga 2010). Sharma and Jaswal (2015) discovered a beneficial connection between experience openness and use of Facebook. Highly openminded individuals prefer Internet interaction, likely because of Facebook's characteristic of meeting fresh individuals with distinct interests and who are geographically dispersed (Correa et al. 2010). In addition, Quercia et al. (2012) found openness as related to the use of Facebook facilities. As a result, the current study hypothesises that:

H3: Openness positively and significantly impacts habitual Facebook usage among Generation Y students.

\section{Agreeableness and habitual Facebook usage}

Agreeableness places people on a continuum regarding their concern for social harmony (Ruzungunde \& Mjoli 2020). Previous research, which has been conducted in different contexts, has shown substantial evidence of the positive relationship between agreeableness and students' preferred learning styles at higher education (Akbar, Khanam \& Manzoor 2020); entrepreneurial intention (Kristanto \& Pratama 2020); and coachability, athletic ability, game performance, team playerness, work ethic and overall sports performance among university athletes (Habib, Waris \& Afzal 2020). However, within the context of this study, it is important to understand how agreeableness influences HFU among Generation Y students. Hence, this study will close this gap by empirically testing the relationship of these two variables. According to Sharma and Jaswal (2015), individuals who are highly agreeable will also be more willing to use Internet, particularly Facebook, through which one can communicate with others. It is discovered that pleasant people are more driven to keep beneficial interactions with others (Campbell \& Graziano 2004). Facebook's SNS is about maintaining healthy relationships with others, interacting with them and maintaining a positive attitude towards them (Sharma \& Jaswal 2015). In addition, AmichaiHamburger and Vinitzky (2010) discovered that agreeableness is positively related to making comments on Facebook. Drawing from the aforementioned elucidations and empirical evidence, it can be hypothesised that:

H4: Agreeableness positively and significantly impacts habitual Facebook usage among Generation Y students.

\section{Conscientiousness and habitual Facebook usage}

Conscientiousness is described as an individual's inclination to demonstrate self-discipline and strive for skill and accomplishment (Greenberg 2011). Conscientiousness categorises people into those who are rational, informed and consider themselves to be competent (Terblanche \& Heyns 2020). This personality dimension is clarified by limited characteristics such as being well organised, cautious, selfdisciplined, accountable and accurate at the high end and being disorganised, impulsive, careless and undependable at the low end (Bell \& Njoli 2016). Previous scholars have discovered conscientiousness as an antecedent or predictor of academic performance (McCredie \& Kurtz 2020), motivation for academic goals (Werner et al. 2019) and as a symptom of insomnia (Akram et al. 2019). Deducing from the aforementioned research studies, it can be noted that there is scant evidence in studies that have examined how conscientiousness would influence HFU. Hence, this study will close this lacuna empirically testing the nexus between conscientiousness and HFU. Conscientiousness has been discovered to be substantially linked to the quality and amount of interpersonal relationships, indicating that conscientious people may use Facebook to search for and retain social associations (Sediman 2013). Ross et al. (2009), however, failed to provide empirical assistance for such proposals, finding no important correlation between awareness and the use of Facebook. In addition, Wehrli (2008) noted that extremely conscientious individuals are not going to devote intense attention or much time to SNSs like Facebook. The present study therefore hypothesised the following:

H5: Conscientiousness negatively and insignificantly impacts habitual Facebook usage among Generation Y students.

\section{Habitual Facebook usage and life satisfaction}

Habitual Facebook use is described as the automatic consumption and use of the said social media platform, which grows as people constantly and routinely access, communicate and use Facebook because of the gratification it provide (Vishwanath 2014). This definition is consistent with the present thinking about habitual media use from the view point of media participation, wherein habits are seen to be acquired by repeating media consumption in stable conditions (LaRose 2010). Previous empirical studies of different contexts have shown positive association between HFU and academic distraction of college students (Feng et al. 2019); knowledge sharing, habit and obligation (Shava \& Chinyamurindi 2018); and social support (Pornsakulvanich 2020). Against the aforementioned background, within the context of this study, it is important to understand how HFU would influence life satisfaction usage among Generation $Y$ students. Hence, there is a need to close this gap by assessing the association between HFU and life satisfaction. Ellison, Steinfield and Lampe (2007) found that using Facebook has a positive influence on the overall life satisfaction of college students. Indian and Grieve (2014) reported that social support received from Facebook positively predicted life satisfaction among people with high social anxiety levels. Similarly, the research by Ong and Lin (2015) showed that Facebook use has a valuable connection with life satisfaction. The following hypothesis has therefore been developed:

H6: Habitual Facebook usage positively and significantly impacts life satisfaction of Generation Y students.

\section{Habitual Facebook usage and psychological well-being}

Farrington (2017) defined psychological well-being as the 'perception of addressing the existential problems of life', 
while Winefield et al. (2012) defined it as a mixture of favourable affective states such as happiness and functioning with ideal effectiveness in individual and social life. Levels of psychological well-being are likely to rely on an individual's internal conditions and the resources and difficulties they face (Farrington 2017). Wright and Cropanzano (2000) pointed out that the advantages of psychological well-being include a rise in the cognitive functioning and health of an individual, and eventually the happy functioning of society. Past empirical studies, which have been conducted in various contexts, provide substantial evidence of positive relationship between psychological well-being and perceived organisational support, career goal development and empowering leadership (Maziriri, Chuchu \& Madinga 2019); experiencing love in everyday life (Oravecz et al. 2020); and social capital among university students (Abbas et al. 2020). However, within the context of this study, it is important to understand how HFU influences the psychological wellbeing of Generation Y students. Hence, this study will close this gap by empirically testing the relationship of these two variables. In the context of this research, it may be observed that when satisfied with their lives, Generation Y students show favourable psychological well-being. In their research aimed at determining the connection between Facebook use and psychological well-being for Baccalaureate Nursing Students at Benha University (Zaki, Sayed and Elattar 2018), they discovered an extremely statistically important connection between psychological well-being and Facebook usage. For this reason, it can be posited that:

H7: Habitual Facebook usage positively and significantly impacts the psychological well-being of Generation Y students.

\section{Life satisfaction and psychological well-being}

Life satisfaction is the mental assessment of the distances between what people want to accomplish and the hedonic profits they have (Çikrıkci 2016). Life satisfaction has been associated with many beneficial results. More favourable academic expectations enhanced academic self-efficacy, ensured higher perceived progress towards objectives and less academic stress, all of which were associated with life satisfaction (O'Sullivan 2011). In terms of its attributions, Buetell (2006) linked life satisfaction to an array of personality, genetic and social-cognitive influences, such as goal-directed behaviour. However, Lucas-Carrasco and Salvador-Carulla (2012) attributed life satisfaction to self-efficacy, while Bastug and Duman (2010) associated it with outcome expectations and support from the environment, and Koohsar and Bonab (2011) related it to intellectual skills. Life satisfaction can also focus on specific life areas such as physical health, wealth, mental health, social relationships and a general sense of achievement (Ye, Yu \& Li 2012). Referring to its effect, life satisfaction has been reported to be linked to a number of personal and organisational factors, such as self-esteem (Rode 2004), personality traits (Zhang \& Howell 2011), work and family roles (Zhao, Qu \& Ghiselli 2011) and job satisfaction (Mafini \& Dlodlo 2014). This study postulates that the life satisfaction is associated with psychological well-being.
This view is in line with Rathore, Kumar and Gautam (2015) who determined the effect of life satisfaction on the psychological well-being of physicians working at Sawai Man Singh (SMS) Medical College and Jaipur Dental College in India, and their findings showed that life satisfaction was an important predictor of physicians' psychological wellbeing. In addition, the connection between life satisfaction and well-being was examined by Leung, Cheung and Liu (2011), and life satisfaction appears to be linked to wellbeing. Nonetheless, when drawing from the abovementioned arguments, which are grounded on empirical evidence, this study hypothesises that:

H8: Life satisfaction positively and significantly impacts the psychological well-being of Generation Y students.

\section{Methodological aspects}

For this study, the research philosophy was positivism. A quantitative research method has therefore been used for this study. The design was appropriate for requesting the necessary data on neuroticism, extraversion, openness, agreeableness, conscientiousness, HFU, life satisfaction and psychological well-being. Furthermore, the strategy allows one to investigate the causal relationships with the constructs used in the research.

\section{Sample and data collection}

This research was conducted among Generation Y students from the South African Business and Technology Institute in Braamfontein, Johannesburg, which is within the Gauteng province of South Africa. This research used Generation Y students as the sample, as this generation is considered to be the most technically knowledgeable population group, and college students are recognised as the early adopters of any new technology (Hwang 2017). At the time of data collection, the students included in the sample had to be active, registered students. A primary identifier of this criterion was the student card with the name and year of enrolment of each student. A list of the registered students has been used as a sampling frame in the database of the institute. This study therefore used a simple random sampling technique because each element of the population had an equal and known chance of being selected as part of the sample (Weideman 2014); for example, each name in the list of students registered in the database of the institute had an equal chance of being selected. The questionnaires made it clear that the respondents' anonymity would be assured and that the research was for educational purposes only. The sample size Raosoft calculator was used to calculate the sample size (Raosoft Inc. 2004). The calculation considered the total student population enrolment of approximately 450 , a $5 \%$ margin of error, $90 \%$ interval of confidence and the recommended $50 \%$ distribution, and returned a minimum sample size of 208 respondents. Of the 208 questionnaires distributed, 200 questionnaires returned were usable, resulting in a response rate of $96.1 \%$. 
TABLE 1: Measurement scales and their sources.

\begin{tabular}{|c|c|c|}
\hline Construct & Description & Cronbach's alpha \\
\hline $\begin{array}{l}\text { Neuroticism: As adapted } \\
\text { from Balta et al. (2018) }\end{array}$ & $\begin{array}{l}\text { - I see myself as an impatient } \\
\text { person. } \\
\text { - I see myself as a pessimistic } \\
\text { person. } \\
\text { - I see myself as a restless person. }\end{array}$ & 0.63 \\
\hline $\begin{array}{l}\text { Extraversion: As adapted } \\
\text { from Alan and Kabadayı } \\
(2016)\end{array}$ & $\begin{array}{l}\text { - I see myself as extraverted. } \\
\text { - I see myself as enthusiastic. } \\
\text { - I see myself as quiet }(R) \text {. }\end{array}$ & 0.81 \\
\hline $\begin{array}{l}\text { Openness: As adapted from } \\
\text { Alan and Kabadayı (2016) }\end{array}$ & $\begin{array}{l}\text { - I see myself as open to new } \\
\text { experiences. } \\
\text { - I see myself as complex. } \\
\text { - I see myself as uncreative (R). }\end{array}$ & 0.70 \\
\hline $\begin{array}{l}\text { Agreeableness: As adapted } \\
\text { from Alan and Kabadayı } \\
\text { (2016) }\end{array}$ & $\begin{array}{l}\text { - I see myself as sympathetic. } \\
\text { - I see myself as warm. } \\
\text { - I see myself as critical (R). }\end{array}$ & 0.76 \\
\hline $\begin{array}{l}\text { Conscientiousness: As } \\
\text { adapted from Alan and } \\
\text { Kabadayı (2016) }\end{array}$ & $\begin{array}{l}\text { - I see myself as dependable. } \\
\text { - I see myself as self-disciplined. } \\
\text { - I see myself as careless (R). }\end{array}$ & 0.76 \\
\hline $\begin{array}{l}\text { Habitual Facebook usage: } \\
\text { As adapted from Shava and } \\
\text { Chinyamurindi (2018) }\end{array}$ & $\begin{array}{l}\text { - I do not think I am able to limit } \\
\text { myself on how I utilise Facebook. } \\
\text { - I am addicted to Facebook. } \\
\text { - I must use Facebook. } \\
\text { - Using Facebook has become } \\
\text { natural to me. }\end{array}$ & 0.85 \\
\hline $\begin{array}{l}\text { Life satisfaction: As adapted } \\
\text { from Valenzuela, Park and } \\
\text { Kee (2009) }\end{array}$ & $\begin{array}{l}\text { - In most ways, my life is close to } \\
\text { my ideal. } \\
\text { - The conditions of my life are } \\
\text { excellent. } \\
\text { - I am satisfied with my life. } \\
\text { - So far, I have gotten the } \\
\text { important things I want in life. } \\
\text { - If I could live my time over, I } \\
\text { would change almost nothing. }\end{array}$ & 0.87 \\
\hline $\begin{array}{l}\text { Psychological well-being: } \\
\text { As adapted from Zeng et al. } \\
\text { (2014) }\end{array}$ & $\begin{array}{l}\text { - I have been cheerful and in good } \\
\text { spirits. } \\
\text { - I have been calm and relaxed. } \\
\text { - I have been active and vigorous. } \\
\text { - When I wake up, I feel freshened } \\
\text { and rested } \\
\text { - My daily life is filled with things } \\
\text { that interest me. }\end{array}$ & 0.91 \\
\hline
\end{tabular}

Note: Please see the full reference list of the article, Maziriri, E.T., 2020, 'The big five personality traits influencing habitual Facebook usage, life satisfaction and psychological well-being of Generation Y students', The Journal for Transdisciplinary Research in Southern Africa 16(1), a751. https://doi.org/10.4102/ td.v16i1.751, for more information.

\section{Measurement instrument and questionnaire design}

The variables under investigation were operationalised from previous studies. Modifications to the scales were made to reflect the study context of Facebook usage. The measurement scales, items used, sources and the Cronbach's alpha values for the scales are indicated in Table 1. The scale indicators were affixed to a strongly disagree (1) to strongly agree (5) Likert-scale continuum.

\section{Respondent profile}

Table 2 shows participant representation. The respondents were asked to report their demographic information, including age, gender and year of study. Most of the respondents were aged between 18 and 22 years (46.5\%), followed by those aged between 23 and 27 years (32.5\%) and aged between 28 and 33 years (21\%), the smallest group. Table 2 also shows respondents' gender. Most respondents
TABLE 2: Sample demographic characteristics.

\begin{tabular}{lcc}
\hline Characteristics & Frequency & $\%$ \\
\hline Age & 93 & 46.5 \\
$18-22$ years & 65 & 32.5 \\
$23-27$ years & 42 & 21 \\
$28-33$ years & 200 & 100 \\
Total & & \\
Gender & 75 & 37.5 \\
Male & 100 & 50 \\
Female & 25 & 12.5 \\
Prefer not to say & 200 & 100 \\
Total & & \\
Year of study & 44 & 22 \\
1 year & 78 & 39 \\
2 year & 58 & 29 \\
3 year & 20 & 10 \\
Postgrad & 200 & 100 \\
Total & &
\end{tabular}

were female, representing $50 \%$ of the total population of the study, followed by $37.5 \%$ male respondents and $12.5 \%$ of the respondents who did not disclose their gender. Table 1 also illustrates respondents' year of study. Most respondents were second-year students $(39 \%)$, followed by third-year students (29\%), first-year students $(22 \%)$ and postgraduate students $(10 \%)$.

\section{Statistical analysis procedure}

The investigator used the Statistical Package for Social Science (SPSS) version 25 to evaluate the data pertaining to the geographical profile of the respondents, while, on the contrary, the latest software version of SMART-PLS 3.2.7 was used to analyse the data captured, as PLS-SEM was preferred to covariance-based SEM because of its improved statistical power in parameter estimates and the maximisation of understood variance (Tajvidi et al. 2018); less compatible than competitive relatives are PLS-SEM and CB-SEM (Rigdon, Ringle \& Sarstedt 2010; Sarstedt, Ringle \& Hair 2014). Nevertheless, PLS-SEM was originally known for its higher prediction over CB-SEM (Hair et al. 2017), although the approximate gaps between the two techniques are quite different. PLS-SEM is analogous to multiple regression analysis and is considered suitable for simultaneous estimation of relationships between one or more independent and dependent variables. This feature makes PLS-SEM especially valuable for research purposes in exploration (Henseler 2017). PLS-SEM incorporates path coefficients, multi-linear regression and confirmatory factor analysis (CFA), which is a multivariate research technique of the second generation. This describes the variability in dependent variables by using structural template analysis (Hair et al. 2010, 2017). Partial Least Squares Structural Equation Modelling works for complex models involving moderation, small samples and are less prone to ordinary multivariate data (Vlajčić et al. 2018). This research study adopted a reflective measurement model in which measurements represent latent variables and the direction of the connection is from the construct or latent variable to the measure 
(Diamantopoulos \& Winklhofer 2001). The statistical analysis performed in this study includes measures such as: (1) measurement model - testing of reliability analysis and validity analysis, and (2) structural model analysis examining the path coefficients between observed coefficients.

\section{Reliability analysis}

Table 3 specifies the different measures that were used to assess the reliability and validity of the constructs for the study.

\section{Measurement model assessment}

The outer model was assessed first by values of composite reliability (CR) (to assess internal consistency), outer loadings (to assess indicator reliability) and average variance extracted (to assess convergent validity). Composite reliability is an appropriate measure of internal consistency reliability because it accounts for the different outer loadings of the indicator variables, whereas Cronbach's alpha assumes all indicators to be equally reliable (Hair et al. 2016). It is vital to indicate that on extraversion, one item was deleted, which is EX1, and on conscientiousness, one item was also deleted, which is CO1, because of the fact that the outer loadings were less than 0.5 (Anderson \& Gerbing 1988). It is imperative to mention that the indicator items from the aforementioned variables that were dropped resulted in improved reliability and validity of those variables. For the other research constructs, the lowest value for each respective item load was 0.698. The recommended value of 0.5 (Anderson \& Gerbing 1988) was consequently surpassed by all individual item loadings. This shows that all measuring instruments are satisfactory and reliable, as all items met the convergent validity thresholds and with more than $50 \%$ of the variance of each item shared with their respective constructs (Fraering \& Minor 2006). As shown in Table 2, the Cronbach's alpha test results ranged between 0.701 and 0.927 , which is above the 0.70 benchmark for acceptable internal consistency reliability (Field 2013).

\begin{tabular}{|c|c|c|c|c|c|c|c|c|c|c|}
\hline \multirow[t]{2}{*}{ Research constructs } & \multirow[t]{2}{*}{ PLS code } & \multirow[t]{2}{*}{ Mean value } & \multirow[t]{2}{*}{ Scale mean } & \multirow[t]{2}{*}{ SD } & \multirow[t]{2}{*}{ Scale SD } & \multicolumn{2}{|c|}{ Cronbach's test } & \multirow[t]{2}{*}{ CR } & \multirow[t]{2}{*}{ AVE } & \multirow[t]{2}{*}{ Factor loadings } \\
\hline & & & & & & Item total & $\alpha$ & & & \\
\hline \multirow[t]{4}{*}{$\overline{\mathrm{NE}}$} & - & - & 4.695 & - & 1.236 & - & 0.862 & 0.916 & 0.786 & - \\
\hline & NE1 & 4.728 & - & 1.314 & - & 0.665 & - & - & - & 0.884 \\
\hline & NE2 & 4.630 & - & 1.224 & - & 0.612 & - & - & - & 0.821 \\
\hline & NE3 & 4.719 & - & 1.160 & - & 0.687 & - & - & - & 0.950 \\
\hline & EX2 & 4.613 & - & 1.094 & - & 0.588 & - & - & - & 0.769 \\
\hline & EX3 & 4.547 & - & 1.180 & - & 0.606 & - & - & - & 0.948 \\
\hline \multirow[t]{4}{*}{ OP } & - & - & 4.230 & - & 1.450 & - & 0.793 & 0.860 & 0.670 & \\
\hline & OP1 & 3.928 & - & 1.477 & - & 0.572 & - & - & - & 0.698 \\
\hline & OP2 & 3.713 & - & 1.593 & - & 0.688 & - & - & - & 0.810 \\
\hline & OP3 & 4.195 & - & 1.425 & - & 0.557 & - & - & - & 0.936 \\
\hline \multirow[t]{3}{*}{ AG } & - & - & 4.456 & - & 1.462 & - & 0.801 & 0.883 & 0.715 & - \\
\hline & AG2 & 4.748 & - & 1.075 & - & 0.755 & - & - & - & 0.815 \\
\hline & AG3 & 4.630 & - & 1.328 & - & 0.652 & - & - & - & 0.849 \\
\hline \multirow[t]{3}{*}{$\mathrm{CO}$} & - & - & 4.351 & - & 1.321 & - & 0.701 & 0.811 & 0.687 & - \\
\hline & $\mathrm{CO} 2$ & 4.513 & - & 1.261 & - & 0.721 & - & - & - & 0.698 \\
\hline & $\mathrm{CO} 3$ & 3.822 & - & 1.168 & - & 0.737 & - & - & - & 0.942 \\
\hline \multirow[t]{5}{*}{ HFU } & - & - & 3.497 & - & 1.247 & - & 0.907 & 0.935 & 0.784 & - \\
\hline & HFU1 & 3.670 & - & 1.188 & - & 0.734 & - & - & - & 0.927 \\
\hline & HFU2 & 3.464 & - & 1.168 & - & 0.830 & - & - & - & 0.810 \\
\hline & HFU3 & 3.307 & - & 1.398 & - & 0.749 & - & - & - & 0.907 \\
\hline & HFU4 & 4.547 & - & 1.232 & - & 0.816 & - & - & - & 0.892 \\
\hline \multirow[t]{4}{*}{ LS } & - & - & 3.491 & - & 1.244 & - & 0.927 & 0.945 & 0.775 & - \\
\hline & LS1 & 3.760 & - & 1.263 & - & 0.734 & - & - & - & 0.810 \\
\hline & LS2 & 3.720 & - & 1.166 & - & 0.773 & - & - & - & 0.900 \\
\hline & LS3 & 3.700 & - & 1.156 & - & 0.756 & - & - & - & 0.899 \\
\hline \multirow[t]{6}{*}{ PWB } & - & - & 3.452 & - & 1.342 & - & 0.891 & 0.920 & 0.697 & - \\
\hline & PWB1 & 3.270 & - & 1.317 & - & 0.845 & - & - & - & 0.853 \\
\hline & PWB2 & 3.570 & - & 1.233 & - & 0.869 & - & - & - & 0.838 \\
\hline & PWB3 & 3.590 & - & 1.213 & - & 0.787 & - & - & - & 0.763 \\
\hline & PWB4 & 3.570 & - & 1.135 & - & 0.838 & - & - & - & 0.859 \\
\hline & PWB5 & 3.600 & - & 1.227 & - & 0.849 & - & - & - & 0.856 \\
\hline
\end{tabular}

AG, agreeableness; AVE, average variance extracted; CO, conscientiousness; CR, composite reliability; EX, extraversion; HFU, habitual Facebook usage; LS, life satisfaction; NE, neuroticism; OP, openness; PLS, partial least squares; PWB, psychological well-being; SD, standard deviation. 
As revealed in Table 3, the lowest CR value of 0.811 is well above the suggested value of 0.6 (Hulland 1999), while the lowest obtained average variance extracted (AVE) value of 0.670 is also above the recommended value of 0.4 (Anderson \& Gerbing 1988). This shows the accomplishment of convergent validity, and this further confirms the excellent internal consistency and reliability of the measuring instruments used. As such, a sufficient level of discriminating validity was revealed by all the variables. These results have generally provided evidence of acceptable levels of reliability of the research scale (Chinomona \& Chinomona 2013). According to Field (2013), discriminant validity refers to items measuring different concepts. Table 4 presents the results of the discriminant validity analysis.

In terms of discriminant validity, all the correlation coefficients of this study fell below 0.70 , thereby confirming the theoretical uniqueness of each variable in this research (Field 2013). In addition, discriminant validity was evaluated using the Hetero-Trait-Monotrait Ratio (HTMT) criterion (Table 2), in spite of recommendations from previous studies (Henseler, Hubona \& Ray 2016; Verkijika \& De Wet 2018), indicating that HTMT is more suitable to evaluate discriminant validity than Fornell-Larcker's commonly used criteria. When taking a more conservative position, discriminant validity is reached when the HTMT value is below 0.9 or 0.85 (Neneh 2019; Verkijika \& De Wet 2018). Table 2 reveals that the highest obtained HTMT value is 0.645 , which is below the conservative value of 0.85 . As such, all the constructs meet the criteria for discriminant validity.

\section{Structural model assessment}

Inner model (structural model) (Figure 2) was assessed to test the relationship between the endogenous and exogenous variables. The path coefficients were obtained by applying a non-parametric, boot-strapping routine (Vinzi et al. 2010), with 261 cases and 5000 samples for the non-return model (two-tailed; 0.05 significance level; no sign changes). The fitness of the model was assessed using the standardised root mean square residual (SRMR) based on the criteria that a good model should have an SRMR value $<0.08$ (Henseler et al. 2016). The structural model in Figure 2 had an SRMR of 0.057, thus suggesting an adequate level of model fitness. In the model, the three endogenous variables (Facebook usage, life satisfaction and

\begin{tabular}{lcccccccc}
\multicolumn{7}{l}{ TABLE 4: Discriminant validity (hetero-trait-monotrait-ratio). } \\
\hline Variables & NE & EX & OP & AG & CO & HFU & LS & PWB \\
\hline NE & 1.000 & - & - & - & - & - & - & - \\
EX & 0.415 & 1.000 & - & - & - & - & - & - \\
OP & 0.549 & 0.438 & 1.000 & - & - & - & - & - \\
AG & 0.444 & 0.381 & 0.287 & 1.000 & - & - & - & - \\
CO & 0.640 & 0.560 & 0.582 & 0.387 & 1.000 & - & - & - \\
HFU & 0.367 & 0.314 & 0.258 & 0.582 & 0.543 & 1.000 & - & - \\
LS & 0.344 & 0.494 & 0.645 & 0.542 & 0.429 & 0.564 & 1.000 & - \\
PWB & 0.463 & 0.395 & 0.590 & 0.596 & 0.530 & 0.504 & 0.554 & 1.000 \\
\hline
\end{tabular}

AG, agreeableness; CO, conscientiousness; EX, extraversion; HFU, habitual Facebook usage; LS, life satisfaction; NE, neuroticism; OP, openness; PWB, psychological well-being. psychological well-being) had $R^{2}$ values of $0.831,0.753$ and 0.874 , respectively, suggesting sufficient predictive accuracy of the structural model (Figure 2).

\section{Outcome of hypotheses testing}

In this study, testing of hypotheses was conducted by path coefficient values, as well as the $t$-values for the structural model obtained from the bootstrapping algorithm. According to Beneke and Blampied (2012), $t$-values indicate whether a significant relationship exists between variables in the model and path coefficients, demonstrating the strength of the relationships in the model. Figure 2 and Table 4 show the standardised path coefficients and their corresponding $t$-values. A statistically significant relationship is expected to have a $t$-value that exceeds 1.96 at a $5 \%$ level of significance (Chin 1998).

\section{Outcome of testing Hypothesis 1: Neuroticism and habitual Facebook usage}

The primary hypothesis expresses that neuroticism positively and significantly impacts HFU among Generation Y students; in this examination, this assumption was reinforced. It can be seen in Figure 2 and Table 4 that neuroticism had a positive impact $(\beta=0.451)$ and was statistically significant $(t=3.137)$ in predicting HFU. This outcome proposes that the higher the level of neuroticism, the higher the level of HFU among Generation Y students. Along these lines, this examination fails to dismiss $\mathrm{H} 1$.

\section{Outcome of testing Hypothesis 2: Extraversion and habitual Facebook usage}

The second hypothesis states that extraversion positively and significantly impacts HFU among Generation Y students. In this study, this supposition is upheld. It can be seen in Figure 2 and Table 4 that extraversion exerts a positive influence $(\beta=0.129)$ and was measurably significant $(t=1.973)$ in predicting HFU. This outcome endorses that the higher the level of extraversion, the higher the level of HFU among Generation Y students. Subsequently, this investigation supports $\mathrm{H} 2$.

\section{Outcome of testing Hypothesis 3: Openness and habitual Facebook usage}

The third hypothesis states that openness positively and significantly impacts HFU among Generation Y students. In this examination, this hypothesis is upheld. Figure 2 and Table 4 indicate that openness exerts a positive impact $(\beta=0.331)$ and is significant $(t=5.984)$ in influencing HFU. This outcome acclaims that the higher the level of openness, the higher the level of HFU among Generation Y students. Thus, this examination supports $\mathrm{H} 3$.

\section{Outcome of testing Hypothesis 4: Agreeableness and habitual Facebook usage}

The fourth hypothesis states that agreeableness positively and significantly impacts HFU among Generation Y students. This study supports this hypothesis. It can be observed in Figure 2 and Table 4 that agreeableness exerts a positive influence $(\beta=0.156)$ and is statistically significant $(t=1.994)$ 


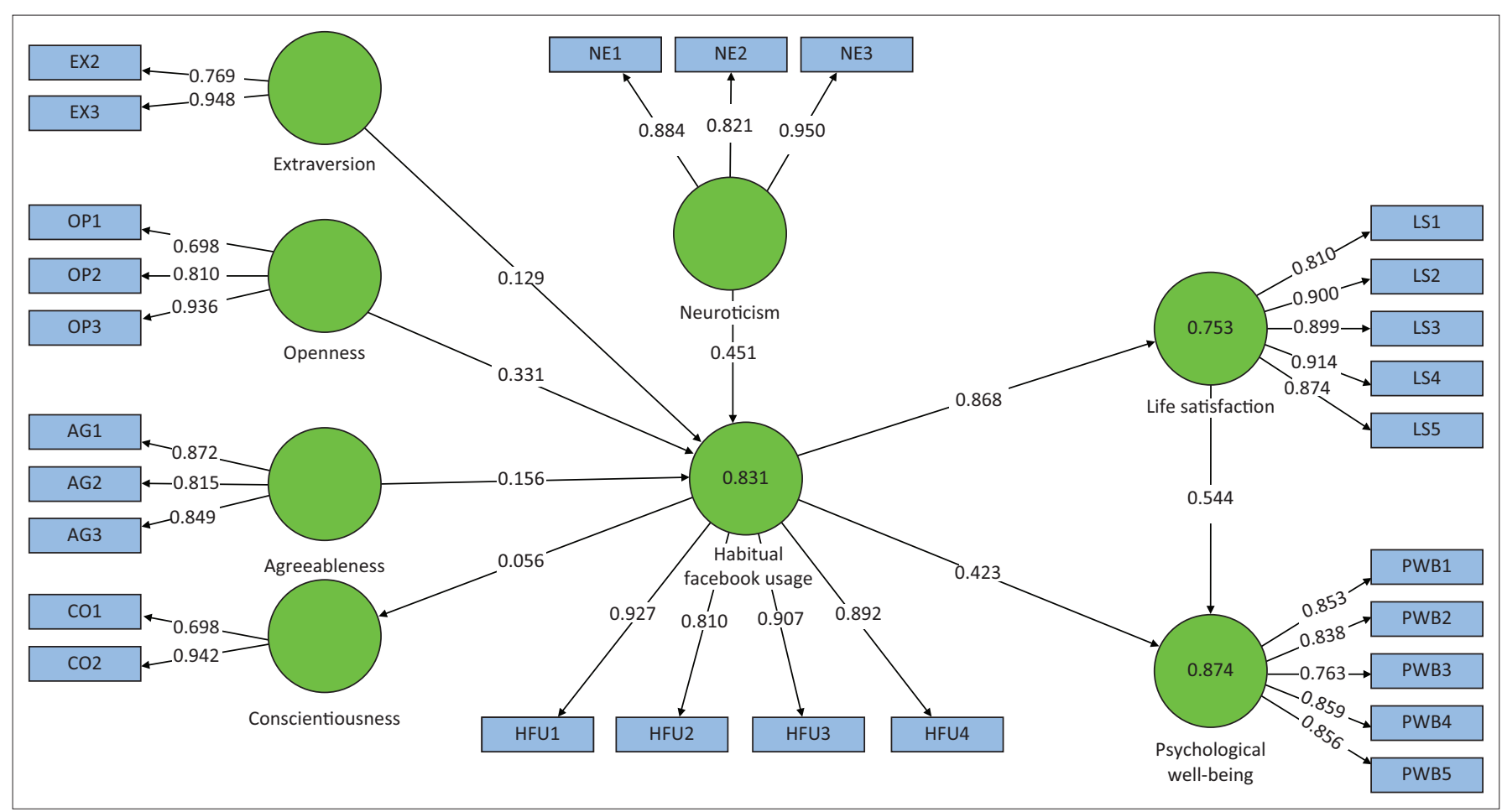

AG, agreeableness; CO, conscientiousness; EX, extraversion; HFU, habitual Facebook usage; LS, life satisfaction; NE, neuroticism; OP, openness; PWB, psychological well-being. FIGURE 2: Structural model.

TABLE 5: Results of structural equation model analysis.

\begin{tabular}{|c|c|c|c|c|c|}
\hline Hypothesis & Proposed hypothesis relationship & Beta coefficients $(\beta)$ & $T$-statistics & $p$ & Decision \\
\hline $\mathrm{H}_{1}$ & $\mathrm{NE} \rightarrow \mathrm{HFU}$ & 0.451 & 3.137 & 0.002 & Positive and significant \\
\hline $\mathrm{H}_{2}$ & $\mathrm{EX} \rightarrow \mathrm{HFU}$ & 0.129 & 1.973 & 0.039 & Positive and significant \\
\hline $\mathrm{H}_{3}$ & $\mathrm{OP} \rightarrow \mathrm{HFU}$ & 0.331 & 5.984 & 0.005 & Positive and significant \\
\hline $\mathrm{H}_{4}$ & $\mathrm{AG} \rightarrow \mathrm{HFU}$ & 0.156 & 1.994 & 0.041 & Positive and significant \\
\hline $\mathrm{H}_{5}$ & $\mathrm{CO} \rightarrow \mathrm{HFU}$ & 0.056 & 0.803 & 0.422 & Positive and insignificant \\
\hline $\mathrm{H}_{6}$ & $\mathrm{HFU} \rightarrow \mathrm{LS}$ & 0.868 & 15.195 & 0.000 & Positive and significant \\
\hline $\mathrm{H}_{7}$ & $\mathrm{HFU} \rightarrow \mathrm{PWB}$ & 0.423 & 4.394 & 0.000 & Positive and significant \\
\hline $\mathrm{H}_{8}$ & $\mathrm{LS} \rightarrow \mathrm{PWB}$ & 0.544 & 6.736 & 0.000 & Positive and significant \\
\hline
\end{tabular}

Note: Arrows signify the relationships between each construct to indicate the proposed hypothesis.

AG, agreeableness; CO, conscientiousness; EX, extraversion; HFU, habitual Facebook usage; LS, life satisfaction; NE, neuroticism; OP, openness; PWB, psychological well-being.

in predicting HFU. This result suggests that the higher the level of agreeableness, the higher the level of HFU among Generation Y students.

\section{Outcome of testing Hypothesis 5: Conscientiousness and habitual Facebook usage}

The fifth hypothesis states that conscientiousness negatively and insignificantly impacts HFU among Generation $Y$ students. In this study, this hypothesis is supported. It can be observed in Figure 2 and Table 4 that conscientiousness exerts a weak positive influence $(\beta=0.056)$ and was statistically insignificant $(t=0.803)$ in predicting HFU.

\section{Outcome of testing Hypothesis 6: Habitual Facebook usage and life satisfaction}

The sixth hypothesis states that HFU positively and significantly impacts life satisfaction. In this study, this hypothesis is supported. It can be observed in Figure 2 and Table 4 that HFU exerts a positive influence $(\beta=0.868)$ and was statistically significant $(t=15.195)$ in predicting life satisfaction.

\section{Outcome of testing Hypothesis 7: Habitual Facebook usage and psychological well-being}

The seventh hypothesis states that HFU positively and significantly impacts psychological well-being. In this study, this hypothesis is supported. It can be observed in Figure 2 and Table 4 that HFU exerts a positive influence $(\beta=0.423)$ and was statistically significant $(t=4.394)$ in predicting psychological well-being. This result suggests that HFU is instrumental in determining the psychological well-being of Generation Y students.

\section{Outcome of testing Hypothesis 8: Life satisfaction and psychological well-being}

The eighth hypothesis states that life satisfaction positively and significantly impacts psychological well-being. In this study, this hypothesis is supported. It can be observed in Figure 2 and Table 4 that life satisfaction exerts a positive influence $(\beta=0.544)$ and was statistically significant $(t=6.736)$ in predicting psychological well-being. This result suggests that when Generation Y students are satisfied with their university life, it then enhances their psychological well-being. 


\section{Ethical consideration}

Permission was obtained from the administration of the South African Business and Technology Institute. The researcher acquired the letter of permission, which allowed him to collect information from the Generation Y students. The approval of ethical clearance was sincerely affirmed, and this study was conducted in compliance with the ethical standards of scholastic science, including, in addition to other issues, the protection of participants' identities and the assurance of the confidentiality of collected data obtained from the participants.

\section{Discussion of results}

The statistical analysis exposed that neuroticism positively and significantly impacts HFU among Generation Y students. This finding has ample support from previous empirical research studies, such as that conducted by Hwang (2017), who discovered that college students with high neuroticism scores predicted Facebook activities including sharing photos with others and updating their profiles. The findings of this study also authenticate the existence of a positive connection between extraversion and HFU. The results obtained in the current study are also not without empirical support. For instance, Koseoglu (2015) found that extraversion was associated with the urge to use Facebook to communicate with others. Empirical evidence was also found in this research that confirmed that there is a positive association between openness and HFU. These results are in line with the works of Bachrach et al. (2012) who discovered that openness is positively correlated with number of users' likes, group associations and status updates on Facebook, which paralleled to the openness characteristics such as seeking new things and ideas and sharing with their friends. It was also discovered that agreeableness positively and significantly impacts HFU among Generation Y students. The results obtained in the current study coincide with the works of Sharma and Jaswal (2015) who asserted that people with the agreeableness personality trait are more inclined towards the usage of the Internet facilities, especially Facebook through which one can interact with others.

In this study, it was also discovered that conscientiousness negatively and insignificantly impacts HFU among Generation Y students. This result suggests that Generation Y students with a conscientiousness personality trait are not interested in using Facebook. A plausible reason might be that conscientious individuals tend to keep away from social network sites (Facebook) because these sites encourage procrastination and are considered a source of distraction from important tasks (Butt \& Phillips 2008). The statistical analysis also exposed that HFU positively and significantly impacts life satisfaction. This result suggests that HFU is instrumental in determining the life satisfaction of Generation Y students. These findings mirror the work of Valenzuela, Park and Kee (2009) who found a positive association between intensity of Facebook use and students' life satisfaction. The results of the analysis suggest that significant relationships can be found between HFU and psychological well-being. These results were like those reported by Jung, Pawlowski and Kim (2017) who explored associations between young adults' Facebook use and psychological wellbeing. Their findings explained the significant association of Facebook use with well-being (Jung et al. 2017). Moreover, the results provide evidence that life satisfaction could predict psychological well-being. These results corroborate findings of a study conducted by Guney (2009) that provided evidence that life satisfaction is strongly associated with psychological well-being.

\section{Theoretical contributions}

As a result of the beneficial impact of personality traits on the $\mathrm{HFU}$, the findings of this research would further help psychology academics who examine personality and its variations among people. In particular, within the framework of social media sites such as Facebook, their knowledge of Generation Y personalities will be improved. For instance, this research has shown that students of the Generation $Y$ cohort with a personality characteristic of conscientiousness are not interested in using Facebook. Therefore, further scholarly introspection should be performed by academics of personality psychology to find out what other aspects trigger the personality traits of Generation $\mathrm{Y}$ students with conscientiousness personality traits. In addition, the findings of the present research revealed that HFU is seen as having the greatest impact on life satisfaction as stated by a path coefficient value of 0.868 . Therefore, for academicians in the field of social media usage, this finding enhances their understanding of the relationship between HFU and life satisfaction, and this is a useful contribution to the existing literature on these two variables.

\section{Practical implications}

On the practitioners' side, the findings of this study provided the significant impact of life satisfaction on Generation $Y$ students' psychological well-being. Therefore, this research argues that campus psychologists as well as campus counselling psychology interns who are accountable for providing psychological assistance to students can benefit from the consequences of these results by comprehensively understanding that Facebook use brings on board satisfaction among students and ultimately enhances their psychological well-being. Furthermore, the findings of the present research revealed that HFU is seen as having the greatest impact on life satisfaction as stated by a path coefficient value of 0.868 , suggesting that campus or university leadership should provide Facebook access to encourage socialisation among Generation Y students, as this eventually enhances their life satisfaction.

\section{Limitations and directions for future research}

In spite of this study's interesting results, its constraints are worthy of notice. Firstly, the findings are not generalisable to 
non-student samples because students constituted the sample for gathering data. Future study therefore requires considering non-students to generalise the outcomes. In addition, the present research was restricted to the province of Gauteng in South Africa, with the other provinces being excluded. This research should be replicated in other South African provinces and other developing countries for comparative outcomes. As other insightful results can be obtained, it is also vital to test the model with other generational cohorts like the Generation Z, Generation X and Baby Boomers, which are less likely to be as techno-savvy as the Generation Y. In conclusion, the quantitative nature of the examination may have produced more illuminating and extravagant information, if a qualitative methodology was considered in this investigation. Future examinations may, as necessary, explore indistinguishable points from the current examination using a blended process technique to improve the expansiveness of the outcomes of the examination. In addition, it was discovered that conscientiousness negatively and insignificantly impacts HFU among Generation Y students. This result suggests that Generation Y students with a conscientiousness personality trait are not interested in using Facebook. A plausible reason might be that conscientious individuals tend to keep away from social network sites (Facebook) because these sites encourage procrastination and are considered a source of distraction from important tasks (Butt \& Phillips 2008).

\section{Acknowledgements}

The author would like to thank the editor and all the anonymous reviewers for their invaluable comments and feedback. The author is also thankful to the students who participated in this study.

\section{Competing interests}

The author pronounces that he has no monetary or individual relationship that may have affected him improperly in composing this article.

\section{Author's contributions}

E.T.M. is the sole author of this research article.

\section{Funding information}

This research received no specific grant from any funding agency in the public, commercial or not-for-profit sectors.

\section{Data availability statement}

Data sharing is not applicable to this article, as no new data were created or analysed in this study.

\section{Disclaimer}

The views and opinions expressed in this article are those of the author and do not necessarily reflect the official policy or position of any affiliated agency of the author.

\section{References}

Abbas, M.A., Eliyana, A., Ekowati, D., Saud, M.M., Raza, M.A. \& Wardani, M.R., 2020 'Data set on coping strategies in the digital age: The role of psychological wellbeing and social capital among university students in Java Timor, Surabaya, Indonesia', Data in Brief 30(1), 1-5. https://doi.org/10.1016/j.dib.2020.105583

Acopio, J.R.B. \& Bance, L.O., 2016, 'Personality traits as predictors of Facebook use', International Journal of Psychology and Counselling 8(4), 45-52. https://do org/10.5897/IJPC2015.0311

Akbar, H., Khanam, A. \& Manzoor, M.S., 2020, 'Relationship among personality traits, extraversion and agreeableness with students preferred learning styles at higher education', Sir Syed Journal of Education \& Social Research 3(1), 1-8. https://doi. org/10.36902/sjesr-vol3-iss1-2020(1-8)

Akram, U., Gardani, M., Akram, A. \& Allen, S., 2019, 'Anxiety and depression mediate the relationship between insomnia symptoms and the personality traits of conscientiousness and emotional stability', Heliyon 5(6), 1-5. https://doi. org/10.1016/j.heliyon.2019.e01939

Alan, A.K. \& Kabadayı, E.T., 2016, 'The effect of personal factors on social media usage of young consumers', Procedia-Social and Behavioral Sciences 235(2016), 595-602. https://doi.org/10.1016/j.sbspro.2016.11.086

Ali, I., 2019, 'Personality traits, individual innovativeness and satisfaction with life', Journal of Innovation \& Knowledge 4(1), 38-46. https://doi.org/10.1016/j. jik.2017.11.002

Amichai-Hamburger, Y. \& Vinitzky, G., 2010, 'Social network use and personality', Computers in Human Behavior 26(6), 1289-1295. http://dx.doi.org/10.1016/j. chb.2010.03.018

Anderson, J.C. \& Gerbing, D.W., 1988, 'Structural equation modeling in practice: A review and recommended two-step approach', Psychological Bulletin 103(3), 411. https://doi.org/10.1037/0033-2909.103.3.411

Bachrach, Y., Kohli, P., Graepel, T., Kosinski, M. \& Stillwell, D., 2012, 'Personality and patterns of Facebook usage', Proceedings of the ACM Web Science Conference, pp. 36-44, viewed 25 April 2019, from https://research.microsoft.com/ pubs/163535/Facebook Personality.michal_29_04_12.pdf.

Balta, S., Emirtekin, E., Kircaburun, K. \& Griffiths, M.D., 2018, 'Neuroticism, trait fear of missing out, and phubbing: The mediating role of state fear of missing out and problematic Instagram use', International Journal of Mental Health and Addiction 18(1), 1-12. https://doi.org/10.1007/s11469-018-9959-8

Bastug, G. \& Duman, S., 2010, 'Examining life satisfaction level depending on physical activity in Turkish and German societies', Procedia - Social and Behavioral Sciences 2(2), 4892-4895. https://doi.org/10.1016/j.sbspro.2010.03.790

Bell, C. \& Njoli, N., 2016, 'The role of big five factors on predicting job crafting propensities amongst administrative employees in a South African tertiary institution', SA Journal of Human Resource Management 14(1), a702. https://doi. org/10.4102/sajhrm.v14i1.702

Beneke, J. \& Blampied, S., 2012, 'Driving consumer perceptions through Facebook: An investigation into empowering brands in the 21st century', in J.M.M. Van Den Berg (ed.), Conference proceedings of the 24th annual conference of SAIMS - 2012, Stellenbosch University, Stellenbosch, September 09-11, 2012 pp. 47-61.

Bergh, Z.C., 2009, 'The nature of personality and fundamental assumptions in personality study', in Z.C. Bergh \& A.L. Theron (eds.), Psychology in the work context, 4th edn., pp. 237-258, Oxford University Press, Cape Town.

Bevan-Dye, A.L. \& Akpojivi, U., 2015, 'South African generation Y students' selfdisclosure on Facebook', South African Journal of Psychology 46(1), 1-16.

Bevan-Dye, A.L. \& Akpojivi, U., 2016, 'South African generation Y students' selfdisclosure on Facebook', South African Journal of Psychology 46(1), 114-129. https://doi.org/10.1177/0081246315602645

Bindu, P.K., 2020, 'Role of extraversion personality on mutual investment decision', Studies in Indian Place Names 40(3), 1917-1926.

Blackwell, D., Leaman, C., Tramposch, R., Osborne, C. \& Liss, M., 2017, 'Extraversion, neuroticism, attachment style and fear of missing out as predictors of social media use and addiction', Personality and Individual Differences 116(1), 69-72. https://doi.org/10.1016/j.paid.2017.04.039

Buetell, N., 2006, Life satisfaction, a Sloan Work and Family Encyclopedia entry, in Sloan Work-Family, Encyclopedia, Boston College, Boston, MA.

Butt, S. \& Phillips, J.G., 2008, 'Personality and self-reported mobile phone use' Computers in Human Behavior 24(2), 346-360. https://doi.org/10.1016/j. chb.2007.01.019

Campbell, L.J. \& Graziano, W., 2004, 'Agreeableness as a moderator of interpersonal conflict', Journal of Personality 69(2), 323-361. https://doi.org/10.1111/14676494.00148

Chakraborty, A., 2016, 'Facebook addiction: An emerging problem', American Journa of Psychiatry Residents' Journal 11(12), 7-9. https://doi.org/10.1176/appi.ajprj.2016.111203

Cheung, C.M.K., Chiu, P. \& Lee, M.K.O., 2011, 'Online social networks: Why do students use Facebook?', Computers in Human Behaviour 27(4), 1337-1343. https://doi.org/10.1016/j.chb.2010.07.028

Chin, W.W., 1998, 'Commentary: Issues and opinion on structural equation modeling' MIS Quarterly 22(1), vii-xvi.

Chininga, T., Rungani, E., Chiliya, N. \& Chuchu, T., 2019, 'Facebook communication and marketing influence on decision-making and choice of University student representatives: A student's perspective' Romanian Journal of Communication and Public Relations 21(2), 7-21. https://doi.org/10.21018/rjcpr.2019.2.274 
Chinomona, R. \& Chinomona, E., 2013, 'The influence of employees' perceptions of organizational politics on turnover intentions in Zimbabwe's SME sector', South African Journal of Business Management 44(2), 15-24. https://doi.org/10.4102/ sajbm.v44i2.156

Choi, C.W., 2020, 'The impacts of consumer personality traits on online video ads sharing intention', Journal of Promotion Management 26(1), 1-20. https://doi.org /10.1080/10496491.2020.1746468

Chu, S. \& Kim, Y., 2011, 'Determinants of consumer engagement in electronic word-of mouth (eWOM) in social networking sites', International Journal of Advertising 30(1), 47-75. https://doi.org/10.2501/IJA-30-1-047-075

Çikrıkci, Ö., 2016, 'The effect of internet use on well-being: Meta-analysis', Computers in Human Behavior 65(1), 560-566. https://doi.org/10.1016/j.chb.2016.09.021

Correa, T., Bachmann, I., Hensley, A.W. \& Gil De Zúñiga, H., 2013, 'Personality and social media use', in E.Y. Li, S. Loh, C. Evans \& F. Lorenzi (eds.), Organizations and social networking: Utilizing social media to engage consumers, pp. 41-61, IG Global, Hershey.

Correa, T., Hinsley, A.W. \& De Zuniga, H.G., 2010, 'Who interacts on the Web? The ( Behavior 26(2), 247-253. https://doi.org/10.1016/j.chb.2009.09.003

Costa, P. \& McCrae R., 1992, 'NEO personality inventory-revised (NEO-PIR) and NEO five-factor inventory (NEO-FFI) professional manual', Psychological assessment resources, Odessa, FL.

Diamantopoulos, A. \& Winklhofer, H.M., 2001, 'Index construction with formative indicators: An alternative to scale development', Journal of Marketing Research 38(2), 269-277. https://doi.org/10.1509/jmkr.38.2.269.18845

Dodoo, N.A. \& Padovano, C.M., 2020, 'Personality-based engagement: An examination of personality and message factors on consumer responses to social media advertisements', Journal of Promotion Management 26(4), 481-503. https://doi. org/10.1080/10496491.2020.1719954

Ellison, N.B., Steinfield, C. \& Lampe, C., 2007, "The benefits of Facebook "friends" social capital and college students' use of online social network sites', Journal of Computer-Mediated Communication 12(4), 1143-1168. https://doi.org/10.1111/ j.1083-6101.2007.00367.x

Farrington, S.M., 2017, 'Psychological well-being and perceived financial performance: An SME perspective', South African Journal of Business Management 48(4), 47-56. https://doi.org/10.4102/sajbm.v48i4.42

Feng, S., Wong, Y.K., Wong, L.Y. \& Hossain, L., 2019, 'The internet and Facebook usage on academic distraction of college students', Computers \& Education 134(1), 41-49. https://doi.org/10.1016/j.compedu.2019.02.005

Field, A., 2013, Discovering statistics using IBM SPSS, 4th edn., Sage, London.

Fong, M., Zhao, K. \& Smillie, L.D., 2020, 'Personality and competitiveness: Extraversion agreeableness, and their aspects, predict self-reported competitiveness and competitive bidding in experimental auctions', Personality and Individual Differences 1-6. https://doi.org/10.1016/j.paid.2020.109907

Foroughi, B., Iranmanesh, M., Nikbin, D., \& Hyun, S.S., 2019, 'Are depression and social anxiety the missing link between Facebook addiction and life satisfaction? The interactive effect of needs and self-regulation', Telematics and Informatic 43(1), 1-11. https://doi.org/10.1016/j.tele.2019.101247

Fraering, M., \& Minor, M.S., 2006, 'Sense of community: An exploratory study of US consumers of financial services', International Journal of Bank Marketing 24(5), 284-306

Greenberg, J., 2011, Behaviour in organisations: Understanding and managing the human side of work, Pearson Education International, London.

Guney, S., 2009, 'Life satisfaction of university students in Turkey', in 1st world positive psychology conference, Pennsylvania, USA, 18-23 June.

Gustavsen, G.W. \& Hegnes, A.W., 2020, 'Individuals' personality and consumption of organic food', Journal of Cleaner Production 245(1), 118772. https://doi. org/10.1016/j.jclepro.2019.118772

Habib, M.B., Waris, S. \& Afzal, S., 2020, 'Personality traits predict in sports performance among University Athletes', The Spark 4(1), 149-159.

Hair, J.F., Babin, B.J., Anderson, R.E., \& Tatham, R.L., 2010, Multivariate data analysis. A global perspective (7th edn.), Prentice-Hall, London.

Hair, Jr, J.F., Hult, G.T.M., Ringle, C. \& Sarstedt, M., 2016, A primer on partial least squares structural equation modeling (PLS-SEM), Sage, Thousand Oaks.

Hair, Jr, J.F., Hult, G.T.M., Ringle, C. \& Sarstedt, M., 2017, A primer on partial least squares structural equation modeling (PLS-SEM), Sage, Thousand Oaks.

Heinström, J., 2003, 'Five personality dimensions and their influence on information behaviour', Information Research 9(1), 9-1.

Henseler, J., 2017, 'Bridging design and behavioral research with variance-based structural equation modeling', Journal of Advertising 46(1), 178-192. https://doi. org/10.1080/00913367.2017.1281780

Henseler, J., Hubona, G. \& Ray, P.A., 2016, 'Using PLS path modeling in new technology research: Updated guidelines', Industrial Management \& Data Systems 116(1) 2-20. https://doi.org/10.1108/IMDS-09-2015-0382

Houghton, D., Pressey, A. \& Istanbulluoglu, D., 2019, 'Who needs social networking? An empirical enquiry into the capability of Facebook to meet human needs and satisfaction with life', Computers in Human Behavior 104(1), 106153. https://doi. org/10.1016/j.chb.2019.09.029

Hulland, J., 1999, 'Use of partial least squares (PLS) in strategic management research: A review of four recent studies', Strategic Management Journal 20(2) A review of four recent studies', Strategic Management Journal 20(2),
195-204. https://doi.org/10.1002/(SICI)1097-0266(199902)20:2<195::AID-SMJ 13>3.0.CO;2-7
Hwang, H.S., 2017, 'The Influence of personality traits on the Facebook addiction', KSII Transactions on Internet \& Information Systems 11(2), 1032-1042. https://doi. org/10.3837/tiis.2017.02.022

Indian, M. \& Grieve, R., 2014, 'When Facebook is easier than face-to-face: Social support derived from Facebook in socially anxious individuals', Personality and Individual Differences 59(1), 102-106. https://doi.org/10.1016/j.paid.2013.11.016

Itani, O., El Haddad, R. \& Kalra, A., 2020, 'Exploring the role of extrovert-introvert customers' personality protype as a driver of customer engagement: Does relationship duration matter?' Journal of Retailing and Consumer Services 53(March), 1-13. https://doi.org/10.1016/j.jretconser.2019.101980

Jariangprasert, N., Jaturapataraporn, J., Sivaraks, P. \& Luangphaiboonsri, S., 2019, 'The influence of food information on Facebook fan pages and Instagram affecting generation $y$ in Thailand on restaurant selection', Veridian E-Journal Silpakorn University (Humanities, Social Sciences and Arts) 12(2), 620-637.

Jeronimus, B.F., Riese, H., Sanderman, R. \& Ormel, J., 2014, 'Mutual reinforcement between neuroticism and life experiences: A five-wave, 16-year study to test reciprocal causation', Journal of Personality and Social Psychology 107(4), 751-64. https://doi.org/10.1037/a0037009

Johnson, C.W.G., 2015, 'Personality traits and their effect on Facebook user habits', Degree of Master of Science dissertation, Colorado State University. Libraries.

Jung, Y., Pawlowski, S.D. \& Kim, H.W., 2017, 'Exploring associations between young adults' Facebook use and psychological well-being: A goal hierarchy approach', International Journal of Information Management 37(1), 1391-1404. https://doi. org/10.1016/j.ijinfomgt.2016.10.005

Kisten, P \& Kluyts, H., 2018, 'An evaluation of personality traits associated with job satisfaction among South African anaesthetists using the Big Five Inventory', Southern African Journal of Anaesthesia and Analgesia 24(1), 9-15. https://doi.or Southern African Journal of Anaesthesia
$\mathrm{g} / 10.1080 / 22201181.2018 .1433986$

Koohsar, A.K.H. \& Bonab, B.H., 2011, 'Relation between quality of attachment and life satisfaction in high school administrators', Procedia - Social and Behavioral Sciences 30(1), 954-958. https://doi.org/10.1016/j.sbspro.2011.10.185

Koseoglu, Y., 2015, 'Facebook, personality and needs-a case from Turkey', Journal of Emerging Trends in Educational Research and Policy Studies 6(1), 40-49.

Kristanto, H. \& Pratama, R.W., 2020, 'Effects of the neuroticism and agreeableness personality types on entrepreneurial intention with subjective norm as moderator', Expert Journal of Business and Management 8(1), 57-66.

Lamb, S., 2009, 'Personality traits and resilience as predictors of job stress and burnout among call centre employees', Master of Social Sciences dissertation, University of the Free State Bloemfontein.

LaRose, R., 2010, 'The problem of media habits', Communication Theory 20(2), 194-222. https://doi.org/10.1111/j.1468-2885.2010.01360.x

Leri, I. \& Theodoridis, P., 2020, 'How do personality traits affect visitor's experience, emotional stimulation and behaviour? The case of wine tourism', Tourism Review. 75, 11-27. https://doi.org/10.1108/TR-05-2019-0148

Leung, A.S., Cheung, H.Y. \& Liu, X., 2011, 'The relations between life domain satisfaction and subjective well-being', Journal of Managerial Psychology 26(2), 155-169. https://doi.org/10.1108/02683941111102182

Lotfi, M., Muktar, S.N.B., Ologbo, A.C. \& Chiemeke, K.C., 2016, 'The influence of the big-five personality traits dimensions on knowledge sharing behavior' Mediterranean Journal of Social Sciences 7(1), 241-250. https://doi.org/10.5901/ mjss.2016.v7n1s1p241

Lucas-Carrasco, R., \& Salvador-Carulla, L., 2012, 'Life satisfaction in persons with intellectual disabilities', Research in Developmental Disabilities 33(4), 1103-1109. http://dx.doi.org/10.1016/j.ridd.2012.02.002

Mafini, C. \& Dlodlo, N., 2014, 'The relationship between extrinsic motivation, job satisfaction and life satisfaction amongst employees in a public organisation', SA Journal of Industrial Psychology 40(1), 1-12. https://doi.org/10.4102/sajip. v40i1.1166

Mayer, C-H., Surtee, S. \&Visser, D., 2016, 'Exploring personality traits, mindfulness and sense of coherence of women working in higher education', SA Journal of Human Resource Management 14(1), a674. https://doi.org/10.4102/sajhrm.v14i1.674

Maziriri, E.T., Chuchu, T. \& Madinga, N.W., 2019, 'Antecedents of psychological wellbeing among workers within small and medium enterprises', SA Journal of Industrial Psychology 45(1), 1-13. https://doi.org/10.4102/sajip.v45i0.1691

McCredie, M.N. \& Kurtz, J.E., 2020, 'Prospective prediction of academic performance in college using self-and informant-rated personality traits', Journal of Research in Personality 85(1), 1-9. https://doi.org/10.1016/j.jrp.2019.103911

Mehroof, M. \& Griffiths, M.D., 2010, 'Online gaming addiction: The role of sensation seeking, self-control, neuroticism, aggression, state anxiety, and trait anxiety', Cyber-Psychology, Behaviour, and Social Networking 13(3), 313-316. https://doi. Cyber-Psychology, Behaviour,
org/10.1089/cyber.2009.0229

Metin-Orta, I. \& Metin-Camgöz, S., 2020, 'Attachment style, openness to experience, and social contact as predictors of attitudes toward homosexuality', Journal of Homosexuality 67(4), 528-553. https://doi.org/10.1080/00918369.2018.1547562

Mhlanga, O., 2019, 'Identification of personality traits affecting entrepreneurial performance in the hospitality subsector: A five-factor personality model', Acto Commercii 19(2), 1-9. https://doi.org/10.4102/ac.v19i2.651

Mondak, J.J., 2010, Personality and the foundations of political behaviour, Cambridge University Press, New York, NY.

Morgan, B. \& De Bruin, K., 2010, 'The relationship between the big five personality traits and Burnout in South African University Students', South African Journal of Psychology 40(2), 182-191. https://doi.org/10.1177/008124631004000208

Moore, K. \& McElroy, J.C., 2012, 'The influence of personality on Facebook usage, wall postings, and regret', Computers in Human Behavior 28(1), 267-274. 
Murugesan, R. \& Jayavelu, R., 2017, 'The influence of big five personality traits and self-efficacy on entrepreneurial intention: The role of gender', Journal of Entrepreneurship and Innovation in Emerging Economies 3(1), 41-61. https://doi. Entrepreneurship and Innovation in
$\mathrm{org} / 10.1177 / 2393957516684569$

Muscanell, N.L. \& Guadagno, R.E., 2012, 'Make new friends or keep the old: Gender and personality differences in social networking use', Computers in Human Behavior 28(1), 107-112. https://doi.org/10.1016/j.chb.2011.08.016

Naude, R., Kruger, S., De Beer, L.T., Saayman, M. \& Jonker, J., 2016, 'The relationship between personality types and leisure time activities amongst Casino employees' workplace expectations', SA Journal of Human Resource Management 14(1), a761. https://doi.org/10.4102/sajhrm.v14i1.761

Neneh, B.N., 2019, 'From entrepreneurial alertness to entrepreneurial behavior: The role of trait competitiveness and proactive personality', Personality and Individual Differences 138(1), 273-279. https://doi.org/10.1016/j.paid.2018.10.020

O'Sullivan, G., 2011, 'The relationship between hope, eustress, self-efficacy, and life satisfaction among undergraduates', Social Indicators Research 101(1), 155-172. https://doi.org/10.1007/s11205-010-9662z

Ong, C.S. \& Lin, M.Y.C., 2015, 'Is being satisfied enough? Well-being and IT postadoption behavior: An empirical study of Facebook', Information Development 32(4), 1042-1054. https://doi.org/10.1177/0266666915587032

Oravecz, Z., Dirsmith, J., Heshmati, S., Vandekerckhove, J. \& Brick, T.R., 2020, 'Psychological well-being and personality traits are associated with experiencing 'Psychological well-being and personality traits are associated with experiencing love in everyday life', Personality and Ind
https://doi.org/10.1016/j.paid.2019.109620

Oyibo, K., Orii, R. \& Vassileva, J., 2017, 'Investigation of the influence of personality traits on Cialdini's persuasive strategies', in Proceedings of the Personalization in Persuasive Technology Workshop, Persuasive Technology 2017, Amsterdam, The Persuasive Technology
Netherlands, 4 April.

Peral, S.L. \& Geldenhuys, M., 2020, 'The indirect relationship between personality and performance through job crafting behaviour', SA Journal of Industrial Psychology/SA
Tydskrif vir Bedryfsielkunde 46(1), 1-12. https://doi.org/10.4102/sajip.v46i0.1715

Pornsakulvanich, V., 2020, 'Excessive use of Facebook: The influence of self-monitoring and Facebook usage on social support', Kasetsart Journal of Social Sciences 39(1), 116-12. https://doi.org/10.1016/j.kjss.2017.02.001

Quercia, D., Diego, L., Casas, J., Pesce, D., Michal, K., Virgilio, A., et al., 2012, 'Facebook and privacy: The balancing act of personality, gender, and relationship currency, in ICWSM (The International Conference on Web and Social Media).

Quintelier, E. \& Theocharis, Y., 2013, 'Online political engagement, Facebook, and personality traits', Social Science Computer Review 31(3), 280-290. https://doi. org/10.1177/0894439312462802

Raosoft Incorporated, 2004, Sample size calculator, viewed 27 January 2019, from https://www.raosoft.com/samplesize.html.

Rathore, S., Kumar, A. \& Gautam, A., 2015, 'Life satisfaction and life orientation as predictors of psychological well being', The International Journal of Indian predictors of psychological well being', The International
Psychology 3(1), 20-27. https://doi.org/10.25215/0301.113

Rigdon, E.E., Ringle, C.M. \& Sarstedt, M., 2010, 'Structural modeling of heterogeneous data with partial least squares', in N.K. Malhotra (ed.), Review of marketing research, pp. 255-296, Emerald Group Publishing Limited, Bradford.

Rode, J.C., 2004, 'Job satisfaction and life satisfaction revisited: A longitudinal test of an integrated model', Human Relations 57(9), 1205-1230. https://doi. org $/ 10.1177 / 0018726704047143$

Ross, C., Orr, E.S., Sisic, M., Arseneault, J.M., Simmering, M.G. \& Orr, R.R., 2009 'Personality and motivations associated with Facebook use', Computers in Human Behaviour 25(2), 578-586. https://doi.org/10.1016/j.chb.2008.12.024

Rothmann, S \& Coetzer E.P., 2003, 'The big five personality dimensions and job performance', SA Journal of Industrial Psychology 29(1), 68-74. https://doi. org/10.4102/sajip.v29i1.88

Ruzungunde, V.S. \& Mjoli, T., 2020, 'An exploration into the role of personality on the experiences of work -family conflict among the mining industry personnel in South Africa', Acta Commercii 20(1), 1-11.

Ryan, T. \& Xenos, S., 2011, 'Who uses Facebook? An investigation into the relationship between the Big Five, shyness, narcissism, loneliness, and Facebook usage', Computers in Human Behaviour 27(5), 1658-1664. https://doi.org/10.1016/j. chb.2011.02.004

Sarstedt, M., Ringle, C.M. \& Hair, J.F., 2014, 'PLS-SEM: Looking back and moving forward', Long Range Planning 47(3), 132-137. https://doi.org/10.1016/j.Irp. forward', Long
2014.02.008

Sediman, G., 2013, 'Self-presentation and belonging on Facebook: How personality influences social media use and motivations', Personality and Individual Differences 54(3), 402-407. https://doi.org/10.1016/j.paid.2012.10.009

Sharma, A \& Jaswal, I., 2015, 'Personality and patterns of Facebook usage', International Journal of Academic Research in Psychology 2(2), 31-44.

Shava, H. \& Chinyamurindi, W.T., 2018, 'Determinants of social media usage among a sample of rural South African youth', South African Journal of Information Management 20(1), a827. https://doi.org/10.4102/sajim.v20i1.827

Statista, 2019, Most famous social network sites worldwide as of July 2018, ranked by number of active users (in millions) [WWW Document], viewed 08 November 2019, from https://www.statista.com/statistics/272014/global-social-networksranked-by-number-of-users/.
Szcześniak, M., Sopińska, B. \& Kroplewski, Z., 2019, 'Big five personality traits and life satisfaction: The mediating role of religiosity', Religions 10(7), 1-16. https://doi. satisfaction: The mediating
org/10.3390/rel10070437

Tajvidi, M., Richard, M.O., Wang, Y. \& Hajli, N., 2018, 'Brand co-creation through social commerce information sharing: The role of social media', Journal of Business Research 82,1-11. https://doi.org/10.1016/j.jbusres.2018.06.008

Tepe, M.S. \& Vanhuysse, P., 2020, 'Taking social policy personally: How does neuroticism affect welfare state attitudes?' Social Policy and Administration 54(4), 20-53. https://doi.org/10.2139/ssrn.2282622

Terblanche, N.H.D. \& Heyns, M., 2020, 'The impact of coachee personality traits, propensity to trust and perceived trustworthiness of a coach, on a coachee's trust behaviour in a coaching relationship', SAJournal of Industrial Psychology/ SA Tydskrif vir Bedryfsielkunde 46(1), 1-11. https://doi.org/10.4102/sajip. v46i0.1707

UI Islam, J., Rahman, Z. \& Hollebeek, L.D., 2017, 'Personality factors as predictors of online consumer engagement: An empirical investigation', Marketing Intelligence \& Planning 35(4), 510-528. https://doi.org/10.1108/MIP-10-2016-0193

Vaag, J., Sund, E.R. \& Bjerkeset, O., 2018, 'Five-factor personality profiles among Norwegian musicians compared to the general workforce', Musicae Scientiae 22(3), 434-445. https://doi.org/10.1177/1029864917709519

Valenzuela, S., Park, N. \& Kee, K.F., 2009, 'Is there social capital in a social network site? Facebook use and college students' life satisfaction, trust, and participation', Journal of Computer-Mediated Communication 14(4), 875-901. https://doi. org/10.1111/j.1083-6101.2009.01474.x

Van Deventer, M. \& Lues, H., 2019, 'Factors influencing generation Y students' university website usage intentions: A case of selected South African universities', Journal of Contemporary Management 16(1), 255-271. https://doi.org/10.35683/ jcm196.0013

Verkijika, S.F. \& De Wet, L., 2018, 'E-government adoption in sub-Saharan Africa' Electronic Commerce Research and Applications 30(1), 83-93. https://doi. org/10.1016/j.elerap.2018.05.012

Viljoen, K., Dube, L. \& Murisi, T., 2016, 'Facebook versus Twitter: Which one is more credible in a South African context?' South African Journal of Information credible in a South African context?' South African Journal of
Management 18(1), a718. https://doi.org/10.4102/sajim.v18i1.718

Vinzi, V.E., Chin, W.W., Henseler, J., \& Wang, H., 2010, Handbook of partial least squares, Vol. 201, Springer, Berlin.

Vishwanath, A., 2014, 'Habitual Facebook use and its impact on getting deceived on social media', Journal of Computer-Mediated Communication 20(1), 83-98. https://doi.org/10.1111/jcc4.12100

Vlajčić, D., Caputo, A., Marzi, G. \& Dabić, M., 2019, 'Expatriates managers' cultural intelligence as promoter of knowledge transfer in multinational companies' Journal of Business Research 94(1), 367-377. https://doi.org/10.1016/j. jbusres.2018.01.033

Wehrli, S., 2008, Personality on social network sites: An application of the five-factor model (Working Paper No. 7), ETH Sociology, Zurich.

Weideman, A., 2014, 'Innovation and reciprocity in applied linguistics', Literator: Journal of Literary Criticism, Comparative Linguistics and Literary Studies 35(1), 1-10. https://doi.org/10.4102/lit.v35i1.1074

Werner, K.M., Milyavskaya, M., Klimo, R. \& Levine, S.L., 2019, 'Examining the unique and combined effects of grit, trait self-control, and conscientiousness in predicting
motivation for academic goals: A commonality analysis', Journal of Research in motivation for academic goals: A commonality analysis', Journal of Rese
Personality 81(1), 168-175. https://doi.org/10.1016/j.jrp.2019.06.003

Winefield, H.R., Gill, T.F., Taylor, A.W. \& Pilkington, R.M., 2012, 'Psychological wellbeing and psychological distress: Is it necessary to measure both?' Psychology of Welland psychological distress: Is it necessary to measure both?
Being 2(3), 1-14. https://doi.org/10.1186/2211-1522-2-3

Wright, T.A. \& Cropanzano, R., 2000, 'Psychological well-being and job satisfaction as predictors of job performance', Journal of Occupational Health Psychology 5(1), 84-94. https://doi.org/10.1037//1076-8998.5.1.84

Ye, S., Yu, L. \& Li, K., 2012, 'A cross-lagged model of self-esteem and life satisfaction: Gender differences among Chinese university students', Personality and Individual Differences 52(4), 546-551. https://doi.org/10.1016/j.paid.2011.11.018

Yesil, S. \& Sozbilir, F., 2013, 'An empirical investigation into the impact of personality on individual innovation behaviour in the workplace', Procedia-Social and BehavioralSciences 81(1), 540-551.https://doi.org/10.1016/j.sbspro.2013.06.474

Zaki, M.M., Sayed, F.S \& Elattar, N.F., 2018, 'Relationship between Facebook use and psychological well-being for baccalaureate nursing students at Benha University', Journal of Nursing and Health Science 1(4), 13-21. https://doi.org/10.1089/ cyber.2010.0061

Zeng, Z., Guo, Y., Lu, L., Han, L., Chen, W. \& Ling, L., 2014, 'Mental health status and work environment among workers in small-and medium-sized enterprises in Guangdong, China-a cross-sectional survey', BMC Public Health 14(1), 1-8. https://doi.org/10.1186/1471-2458-14-1162

Zhang, J. \& Howell, R.T., 2011, 'Do time perspectives predict unique variance in life satisfaction beyond personality traits?' Personality and Individual Differences 50(8), 1261-1266. https://doi.org/10.1016/j.paid.2011.02.021

Zhao, X.R., Qu, H. \& Ghiselli, R., 2011, 'Examining the relationship of work-family conflict to job and life satisfaction: A case of hotel sales managers', International Journal of Hospitality Management 30(1), 46-54. https://doi.org/10.1016/j. ijhm.2010.04.010 